\begin{tabular}{c}
\hline JAUR, 5 (1) Bulan 2021 ISSN 2599-0179 (Print) ISSN 2599-0160 (Online) \\
JAUR \\
(Journal of Architecture and Urbanism Research) \\
Available online http://ojs.uma.ac.id/index.php/jaur
\end{tabular}

\title{
Pusat Pertunjukkan Kesenian Jawa Di Pekanbaru Dengan Pendekatan Arsitektur Jawa
}

\section{Center For Javanese Art Performance In Pekanbaru With Javanese Architectural Approach}

\author{
${ }^{*}$ Wahyu Suciono'), Muhammad Rijal'2), Gun Faisal ${ }^{3)}$ \\ 1) Mahasiswa Jurusan Arsitektur, Fakultas Teknik, Universitas Riau, Indonesia \\ 2) Dosen Jurusan Arsitektur, Fakultas Teknik, Universitas Riau, Indonesia \\ 3) Dosen Jurusan Arsitektur, Fakultas Teknik, Universitas Riau, Indonesia
}

Diterima: Agustus 2021; Disetujui: September 2021; Dipublikasi: Oktober 2021

*Coresponding Email: wahyu.suciono1056@student.unri.ac.id

\begin{abstract}
Abstrak
Perkembangan tekonologi dan kemajuan zaman menjadikan berbagai budaya dan kesenian bangsa asing masuk secara terus menerus menggerus budaya dan seni tradisional bangsa Indonesia. Masuknya budaya asing menjadi salah satu faktor yang sangat berpengaruh terhadap menurunnya minat masyarakat terhadap warisan budaya dan seni dari nenek moyangnya sendiri, terutama generasi muda yang lebih senang dengan budaya dan seni modern yang menjamur saat ini sehingga lupa dengan identitas mereka sebagai orang jawa. Budaya asing membuat masyarakat mudah menerima kebudayaan tersebut tanpa dicerna terlebih dahulu. Tanpa disadari, kebudayaan dan kesenian daerah kini sudah mulai terlupakan, ditinggalkan dan ditelan oleh kebudayaan asing. Oleh karena itu, keberadaan Pusat Pertunjukkan Kesenian Jawa berfungsi untuk memperkenalkan keaneragaman kesenian Jawa dengan memberikan pertunjukkan seni, pelatihan, pengembangan akan keseniankesenian Jawa kepada masyarakat Jawa Riau, juga sebagai sarana pelestarian kesenian daerah dan sarana rekreasi. Dalam perancangan Pusat Pertunjukkan Kesenian Jawa tidak hanya mengutamakan dalam hal penampilan sebuah arsitektur, kemegahan bangunannya saja, melainkan kandungan nilainilai dari arsitektur tersebut dalam menanggapi sebuah permasalahan dan memikirkan kesesuaian dengan lingkungan sekitar. Bangunan-bangunan tersebut mengikuti perkembangan arsitekturarsitektur luar yang semakin canggih, namun melupakan arsitektur daerahnya. Melalui penerapan Tema Arsitektur Jawa diharapkan dapat mengangkat kembali nilai-nilai arsitektur Jawa yang sudah mulai punah.
\end{abstract}

Kata Kunci: Pusat Pertunjukkan, Kesenian Jawa, Arsitektur Jawa

\section{Abstract}

Technological developments and the progress of the times have made various cultures and arts of foreign nations enter continuously eroding the traditional culture and arts of the Indonesian nation. The entry of foreign culture is one of the factors that greatly influences the decline in people's interest in the cultural and 
artistic heritage of their own ancestors, especially the younger generation who are more happy with modern culture and art that are mushrooming at this time so they forget their identity as Javanese. Foreign culture makes it easy for people to accept this culture without being digested first. Without realizing it, local culture and arts have now begun to be forgotten, abandoned and swallowed up by foreign cultures. Therefore, the existence of the Javanese Arts Performance Center serves to introduce the diversity of Javanese arts by providing art performances, training, development of Javanese arts to the people of Riau Java, as well as a means of preserving regional arts and recreational facilities. In designing the Javanese Arts Performance Center, it does not only prioritize the appearance of an architecture, the splendor of the building, but the content of the values of the architecture in responding to a problem and thinking about its suitability with the surrounding environment. These buildings follow the development of increasingly sophisticated external architectures, but forget the regional architecture. Through the application of the Javanese Architecture Theme, it is hoped that it can bring back the values of Javanese architecture which are starting to become extinct.

\section{Keywords: Performance Center, Javanese Arts, Javanese Architecture}

How to Cite: Suciono W, Muhammad R, Gun F, (2021), Pusat Pertunjukan Kesenian Jawa di Pekanbaru dengan Pendekatan Arsitektur Jawa . JAUR (Journal of Architecture and Urbanism Research). 5 (1): 59-67 


\section{PENDAHULUAN}

Indonesia terdiri dari Sabang sampai Merauke yang memiliki keaneragaman budaya dan kesenian yang sangat terkenal dan bernilai produksi luar biasa, sebagai hasil dari usaha bangsa Indonesia sendiri. Menurut Sudarso (2006), seni merupakan karya manusia untuk mengkomunikasikan pengalaman batin yang disajikan secara menarik sehingga dapat merangsang adanya pengalaman batin yang dirasakan pada manusia yang menikmatinya. Sedangkan pusat pertunjukkan memiliki arti sebagai pusat dari seluruh aktivitas secara kompleks, yang didalamnya tersaji pertunjukkan seni, pengetahuan, moral, pelatihan, perkumpulan, dan lain-lainnya yang menyediakan para seniman menunjukkan ekspresi diri melalui wujud seni yang dimilikinya untuk menghibur masyarakat. Kesenian yang dikembangkan disini adalah kesenian Jawa.

Kesenian Jawa secara garis besar berasal dari tiga daerah yaitu, Banyumasan, Jawa Tengah-Daerah Istimewa Yogyakarta dan Jawa Timuran. Suku Jawa menempati peringkat pertama dengan jumlah terbanyak di Indonesia yaitu 40,22\% dari jumlah penduduk Indonesia. Peringkat kedua adalah suku sunda sebesar $15,50 \%$. Selanjutnya suku-suku lainnya memiliki porsi dibawa $5 \%$ penduduk Indonesia. Wadah yang diperlukan untuk itu semua adalah Pusat Pertunjukkan Kesenian Jawa yang terletak di Kota Pekanbaru, Riau. Bedasarkan data Badan Pusat Statistik Tahun 2010 menunjukkan jumlah Suku Jawa di Provinsi Riau berada pada peringkat dua dengan presentase $29,20 \%$ setelah suku asli di Provinsi Riau yaitu Suku Melayu dengan presentase $33,20 \%$. Semangat dalam melestarikan Kesenian Jawa harus didukung dengan fasilitas pelestarian, seperti fasilitas ruang gerak untuk berkarya dan beraktifitas yang memadai sehingga akan terjalin harmoni dalam sebuah wadah yaitu Pusat Pertunjukkan.

Menurut Zein (1985), Arsitektur Jawa adalah Arsitektur yang lahir, tumbuh, berkembang, didukung dan digunakan oleh masyarakat Jawa. Arsitektur Jawa memiliki prinsip yang menarik yaitu, ayu, ayom, dan ayem. Alasan dipilihnya Arsitektur Jawa karena untuk mengenal dan mempelajari seni Jawa harus juga mengenal Arsitektur Jawa agar penyampaian makna seni yang ditampilkan dalam pertunjukkan seni Jawa lebih dipahami dengan bentuk visual bangunannya. Dapat disimpulkan Pusat Pertunjukkan Kesenian ini untuk mewadahi segala aktifitas pengembangan dan pelestarian terhadap kesenian Jawa dan dilengkapi dengan fasilitas penunjang kegiatan dengan berpedoman pada persyaratan-persyaratan yang ada.

Perancangan Pusat Pertunjukkan Kesenian Jawa di Pekanbaru dengan Pendekatan Arsitektur Jawa memiliki tantangan masalah sebagai berikut:

Bagaimana menyusun fungsi dan kegiatan yang akan diwadahi melalui fasilitasfasilitas yang efektif dan efisien dalam perancangan Pusat Pertunjukkan Kesenian Jawa? Bagaimana menerapkan Prinsip-prinsip Arsitektur Jawa yang ayu, ayom, dan ayem pada desain bangunan Pusat Pertunjukkan Kesenian Jawa? Bagaimana menentukan konsep yang sesuai dengan karakteristik Arsitektur Jawa sehingga pada penataan bangunan Pusat Pertunjukkan Kesenian Jawa memberikan kesan menarik dan menampilkan makna Arsitektur Jawa?

Menurut Poerdarminto (2003), pusat merupakan semua yang diarahkan atau dikumpulkan pada pokok-pokok yang menjadi pumpunan (berbagai urusan, hal dan sebagainya). Sedangkan Pertunjukkan merupakan penampilan sebuah karya (musik, tari, kerajinan dan lainnya) yang ditampilkan 
dihadapan penonton oleh seorang seniman ataupun orang lain. Pertunjukkan memberikan hiburan, motivasi dan pendidikan melalui media gerak, suara, dan lainnya yang tersampai jelas kepada para penonton.

Dari uraian diatas dapat disimpulkan bahwa pusat pertunjukkan merupakan titik kumpul atau tujuan utama yang didalamnya terdapat berbagai penampilan mulai dari penampilan musik, tari, pameran hasil kerajinan, dan lainnya yang bertujuan memberi informasi dan edukasi bagi masyarakat.

Kesenian merupakan ekspresi dari kebudayaan yang ditampilkan dalam sebuah gerak maupun benda hasil dari kreatifitas masyarakat untuk mengenal identitasnya. Berikut pengertian seni menurut para ahli:

Geertz (1993), seni merupakan sistem budaya. Penilaian tersebut diberikan, dilekatkan, dan dibiasakan oleh masyarakat sebagai pedoman interaksi pada warga masyarakat.

Wardana (1990), kesenian merupakan buah budi manusia dalam menyatakan nilainilai, keindahan dan keluhuran lewat berbagai media seperti seni gerak, seni suara, seni bangunan, seni rupa, dan seni sastra.

Sudarmaji (1979), kesenian merupakan pengembangan dari kata seni yang mempunyai arti halus dan kecil, karena karya seni pada umumnya adalah karya yang halus seperti karya seni ukir kayu,

Damajanti (2006), seni merupakan sebuah inti atau wujud dari kreatifitas manusia, yang nantinya tidak bisa dihakimi dengan nilai tertentu. Karena sebuah kesenian dapat menimbulkan efek yang berbeda-beda bagi setiap orang. Sehingga setiap individu memiliki parameter tersendiri untuk menilai sebuah kesenian.

Berdasarkan penjelasan para ahli dapat disimpulakan bahwa kesenian bukan hanya berupa penampilan fisik semata namun juga penampilan perasaan yang dapat mengajak orang lain atau penikmatnya ikut merasakan perasaan penciptanya.
Pitana (2001), menyebutkan bahawa arsitektur Jawa merupakan karya masyarakat Jawa yang berupa tempat tinggal atau masayarakat Jawa menyebutnya dengan Omah. Omah terdiri dari dua kata yiatu om, yang diartikan sebagai angkasa dan bersifat laki-laki (kebapakan), dan mah diartikan lemah (tanah) dan bersifat perempuan (keibuan).Arsitektur Jawa timbul karena disebabkan adanya masyarakat Jawa dengan karakteristiknya. Perkembangan arsitektur Jawa dapat dikelompokkan menjadi dua keaneragaman tampilan arsitektur Jawa. Pertama, tampilan yang mencoba untuk menghadirkan kembali arsitektur Jawa sebagaimana aslinya. Kedua, mencoba menampilkan arsitektur Jawa yang kekinian sebagai penggugah dalam melestarikan Arsitektur tradisional Jawa namun masih dikenal dan dirasakan sebagai arsitektur Jawanya.

Prinsip-Prinsip pada Arsitektur Jawa, Menurut Zein (1985) Arsitektur Jawa adalah Arsitektur yang lahir, tumbuh, berkembang, didukung dan digunakan oleh masyarakat Jawa. Arsitektur Jawa lahir dan hidup karena ada masyarakat Jawa serta memegang nilai fungsi dan filosofi Ayu, Ayem, dan Ayom. Arsitektur Jawa memiliki prinsip-prinsip yang dijabarkan sebagai berikut:

a. Arsitektur Jawa itu Ayu, Ayu memiliki beberapa arti, diantaranya sebagai berikut:

b. Estetis, Estetis membahas pada keindahan bangunan

c. Simbolis, Bentuk pada bangunan Jawa digambarkan sebagai lambang sehingga ada bentuk atapnya disimbolkan sebagai alam semesta.

d. Kaya, Arsitektur Jawa memiliki lima rumah adat tradisional paling terkenal yaitu panggangpe, kampung, limasan, joglo, dan tajug.

e. Memiliki jati diri, Jati diri menunjukkan siapa pemilik dari pemiliki bangunan.

Arsitektur Jawa itu Ayom, Ayom dalam arsitektur Jawa dimaksudkan sebagai: 
a. Teduh dan rindang, Bangunan arsitektur Jawa bagaikan pohon beringin yang memberikan keteduhan bagi para penghuninya.

b. Terlindung dari kekuatan metafisika yang merugikan.

c. Arsitektur Jawa itu Ayem, Ayem artinya tentram. Tentram dalam arsitektur Jawa terpenuhi oleh beberapa faktor, antara lain sebagai berikut:

d. Kesejahteraan, Arsitektur Jawa diciptakan untuk memenuhi kebutuhan manusia baik secara lahir maupun batinnya.

e. Keamanan, Bangunan-bangunan Jawa berdiri kokoh dan megah dengan mahkota atapmya yang didukung dengan sistem struktur rangka kayu yang fleksibel dan juga kuat.

f. Keselarasan

g. Arsitektur Jawa berusaha menyelaraskan diri dengan alam fisik disekitarnya.

\section{METODE PENELITIAN}

Paradigma, Perancangan Pusat Pertunjukkan Kesenian Jawa di Pekanbaru dengan pendekatan Arsitektur Jawa merupakan upaya untuk mewadahi kebutuhan masyarakat Jawa Riau sebagai pusat berkumpul dan untuk lebih mengenal kesenian Jawa serta untuk membangkitkan kembali nilai-nilai seni Jawa yang kini berkurang eksistensinya dikalangan masyarakat Jawanya sendiri. Pada pendekatan Arsitektur Jawa memiliki kesesuaian untuk di terapkan pada bangunan Pusat Pertunjukkan Kesenian Jawa karena untuk mempelajari dan mengenal budaya Jawa maka harus juga dengan mengenal arsitektur Jawa agar penyampaian nilai-nilai budaya Jawa lebih dipahami dengan bentuk visual bangunannya, serta dengan menerapkan karakteristik Arsitektur Jawa yang Ayu, Ayom dan Ayem menjadikan bangunan Bangunan Pusat Pertunjukkan Kesenian Jawa menjadi berkarakter Jawa yang kental.
Strategi Perancangan, Strategi perancangan Pusat Pertunjukkan Kesenian Jawa di Pekanbaru dengan Pendekatan Arsitektur Jawa yaitu dimulai dengan studi literature, analisa fungsi, analisa site, pemograman ruang, penzoningan, konsep, bentukkan massa, system bangunan, denah, sirkulasi, fasad, lansekap, dan mendapatkan hasil desain.

\section{Metode Pengumpulan Data,}

Pengumpulan dan pengolahan data yaitu data primer dan data sekunder. Pengumpulan data di dapat dari data primer dan sekunder di gunakan metode sebagai berikut: Data primer didapat dengan melakukan survei lapangan (observasi) dan dokumentasi sedangkan data sekunder didapat dengan melakukan pencarian jurnal, skripsi, tesis, disertasi, buku, dan media.

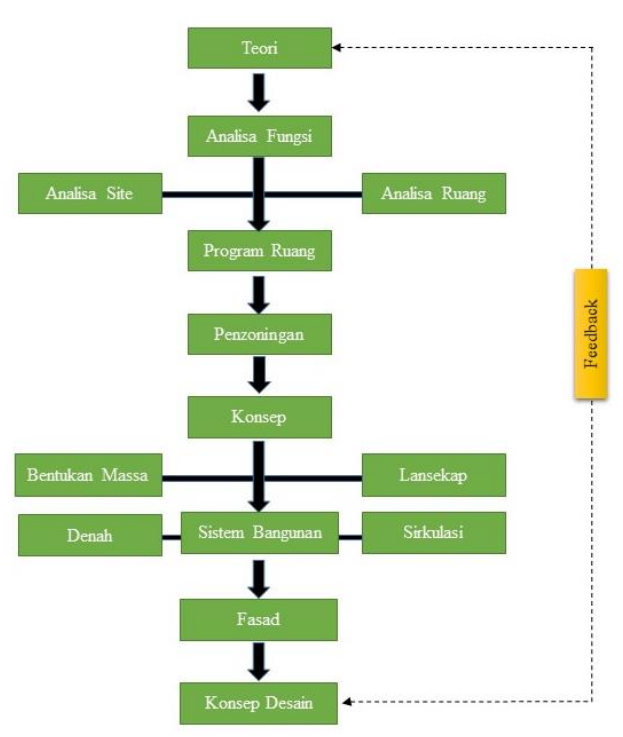

Gambar 1. Bagan Alur Perancangan (Sumber: Analisa Penulis, 2020) 


\section{PEMBAHASAN}

Lokasi Perancangan

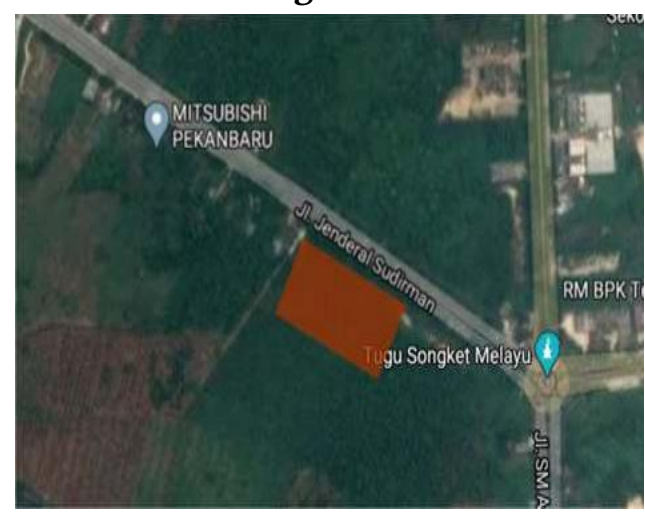

Gambar 2. Lokasi Perancangan

(Sumber Analisa Penulis, 2020)

Lokasi tapak berada di tepi jalan Tuanku Tambusai Kecamatan Tampan, Pekanbaru, Provinsi Riau. Tapak memiliki luas lahan $25000 \mathrm{~m}^{2}(2.5 \mathrm{Ha})$,

KDB 50\% (sedang-Tinggi), kontur tidak rata dengan kondisi tanah gambut dan kondisi existingberupa lahan kosong

Kebutuhan ruang yang diperlukan dalam perancangan Pusat Pertunjukkan Kesenian Jawa, berdasarkan Tabel 1. yaitu dengan menghitung jumlah kegiatan serta fasilitas ruang yang dibutuhkan dalam gedung. Sehingga didapatkan besaran ruang terhadap fungsi dari ruangan tersebut yaitu sebagai berikut:

Tabel 1. Kebutuhan Ruang

\begin{tabular}{|c|c|}
\hline Nama Ruang dan Bangunan & Luas $\left(\mathrm{m}^{2}\right)$ \\
\hline $\begin{array}{l}\text { Ruang pengelola dan } \\
\text { administrasi }\end{array}$ & $1.013,48 \mathrm{~m}^{2}$ \\
\hline Ruang gedung pertunjukkan & $1.922,88 \mathrm{~m}^{2}$ \\
\hline Ruang galeri & $497,64 \mathrm{~m}^{2}$ \\
\hline Ruang sanggar teater & $305,5 \mathrm{~m}^{2}$ \\
\hline Ruang sanggar musik dan tari & $312 \mathrm{~m}^{2}$ \\
\hline Ruang workshop & $432,64 \mathrm{~m}^{2}$ \\
\hline $\begin{array}{l}\text { Ruang retail kerajinan dan } \\
\text { foodcourt }\end{array}$ & $791,96 \mathrm{~m}^{2}$ \\
\hline Ruang pendukung & $937,3 \mathrm{~m}^{2}$ \\
\hline Area parkir & $5980 \mathrm{~m}^{2}$ \\
\hline $\begin{array}{l}\text { Total Keseluruhan Luas } \\
\text { Bangunan }\end{array}$ & $12.193,4 \mathrm{~m}^{2}$ \\
\hline
\end{tabular}

(Sumber: Analisa Penulisi, 2020)
Penzoningan, Pada Pusat Pertunjukkan Kesenian Jawa di Pekanbaru dengan Pendekatan Arsitektur Jawa terbagi menjadi beberapa zona yaitu, zona berkumpul, zona pertunjukkan pewayangan, dan zona pertunjukkan kesenian Jawa.

Penerapan Tema, Perancangan Pusat Pertunjukkan Kesenian Jawa di Pekanbaru menerapkan tema berdasarkan prinsip-prinsip Arsitektur Jawa yang ayu, ayom, dan ayem kedalam bangunan perancangan.

Tabel 2. Analisis Penerapan Prinsip-Prinsip Arsitektur Jawa ke dalam Perancangan

\begin{tabular}{|l|l|l|}
\hline No & $\begin{array}{l}\text { Prinsip-Prinsip } \\
\text { Arsitektur Tepian } \\
\text { Air }\end{array}$ & Tanggapan \\
\hline 1. & $\begin{array}{l}\text { Arsitektur Jawa } \\
\text { itu ayu }\end{array}$ & $\begin{array}{l}\text { menerapkan penggunaan bentuk } \\
\text { atap joglo tradisional Jawa dengan } \\
\text { sistem pengulangan. }\end{array}$ \\
\hline 2. & $\begin{array}{l}\text { Arsitektur Jawa } \\
\text { itu Ayom }\end{array}$ & $\begin{array}{l}\text { Penerapan prinsip ayom yaitu } \\
\text { menggunakan bentuk ornament } \\
\text { dengan simbol sebagai pelindung } \\
\text { dari kekuatan metafisika yang } \\
\text { merugikan penghuni bangunan. }\end{array}$ \\
\hline 3. & $\begin{array}{l}\text { Arsitektur Jawa } \\
\text { itu Ayem }\end{array}$ & $\begin{array}{l}\text { Penerapan prinsip ayem pada } \\
\text { bangunan Pusat Pertunjukkan } \\
\text { Kesenian Jawa di terapkan dengan } \\
\text { penggunaan struktur yang kokoh } \\
\text { yaitu struktur dan bentuk denah } \\
\text { yang hampir sama dengan struktur } \\
\text { yang ada pada rumah tradisional } \\
\text { Jawa. }\end{array}$ \\
\hline
\end{tabular}

(Sumber: Analisa Penulis, 2020)

Konsep perancangan Pusat Pertunjukkan Kesnian Jawa berasal dari bentuk joglo. Atap joglo yang berbentuk piramida melambangkan sebuah gunung dimana menurut kepercayaan adat Jawa gunung adalah simbol dari segala hal yang sakral dan dipercaya sebagai tempat tinggalmya para Dewa. Joglo memiliki empat tiang utama yang disebut dengan soko guru. 


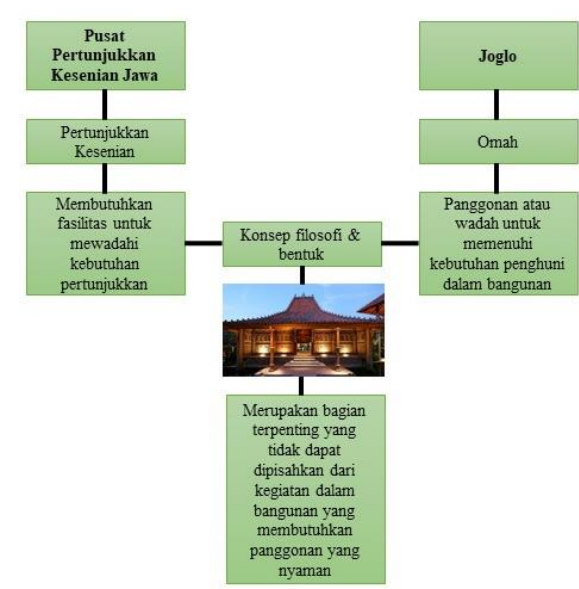

Gambar 3. Bagan Konsep

(SumberAnalisa Penulis, 2020)

Konsep Bentukkan, Konsep perancangan Pusat Pertunjukkan Kesnian Jawa berasal dari bentuk joglo. Atap joglo yang berbentuk piramida melambangkan sebuah gunung dimana menurut kepercayaan adat Jawa gunung adalah simbol dari segala hal yang sakral dan dipercaya sebagai tempat tinggalmya para Dewa.

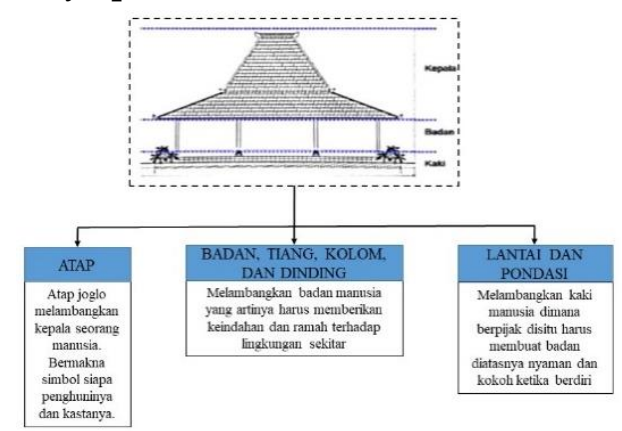

Gambar 4. Diagram Konsep Bentukkan (Sumber: Analisa Penulis, 2020)

Konsep Bangunan, Pengambilan bentuk joglo berdasarkan dengan fungsi dan tema Arsitektur Jawa yang mengedepankan sisi ayu, ayom,dan ayem bagi penghuninya.
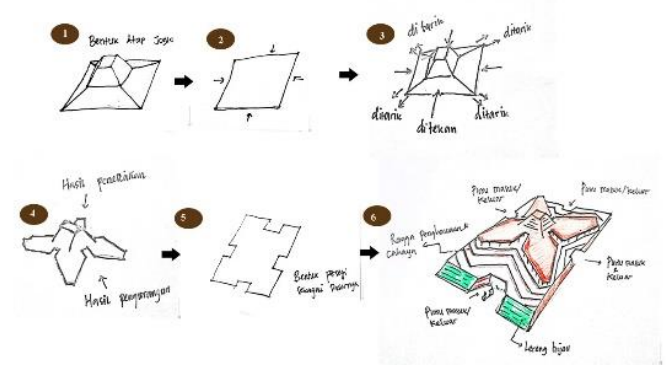

Gambar 5. Visualisasi Bentuk Konsep Bangunan (Sumber: Analisa Penulis, 2020)

Konsep Facade, menggunakan bukaan yang besar pada jendela, pintu dan anginangin. Hal ini bertujuan agar cahaya dapat membantu penerangan pada siang hari dan berguna untuk pemanfaatan penguapan suhu dari dalam bangunan.

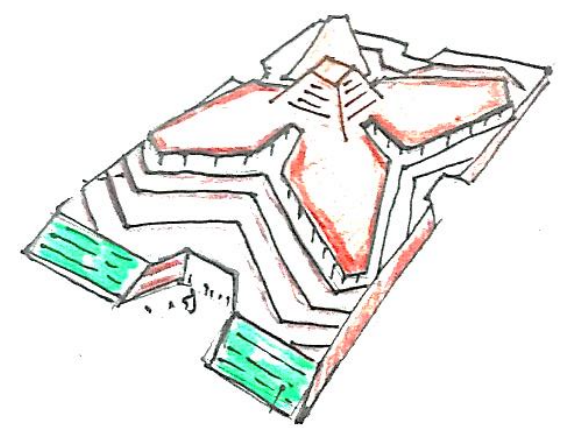

Gambar 6. Facade Bangunan

(Sumber: Analisa Penulis, 2020)

Konsep Landscape, disesuaikan dengan konsep utama pada rumah tradsional Jawa terdapat banyak area hijau untuk menyesuaikan suasana alam pada kehidupan manusia.

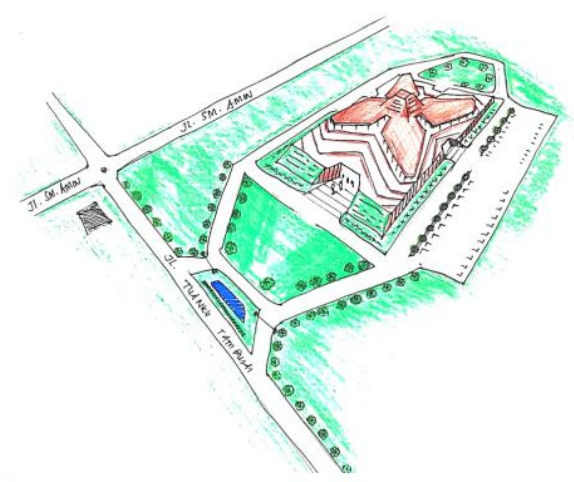

Gambar 7. Konsep Landscape

(Sumber: Analisa Penulis, 2020)

Konsep Vegetasi, Penentuan konsep vegetasi dengan tanaman yang paling menonjol adalah pohon beringin karena tanaman ini banyak dipercaya oleh masyarakat Jawa sebagai perlambang pohon hayat atau pohon kehidupan. 


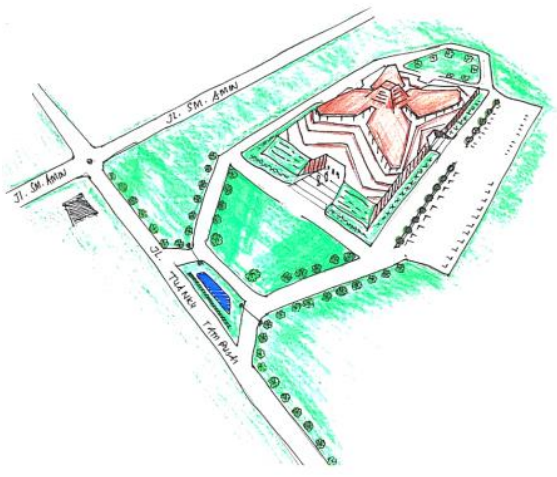

Gambar 8. Konsep Vegetasi

(Sumber: Analisa Penulis, 2020)

Konsep Sirkulasi, untuk Transportasi kendaraan umum hanya akan melintasi area depan saja selanjutnya langsung menuju keluar. Pejalan kaki langsung masuk menuju bangunan, sedangkan kendaraan pribadi (pengunjung dan pengelola) langsung menuju ke area parkiran.

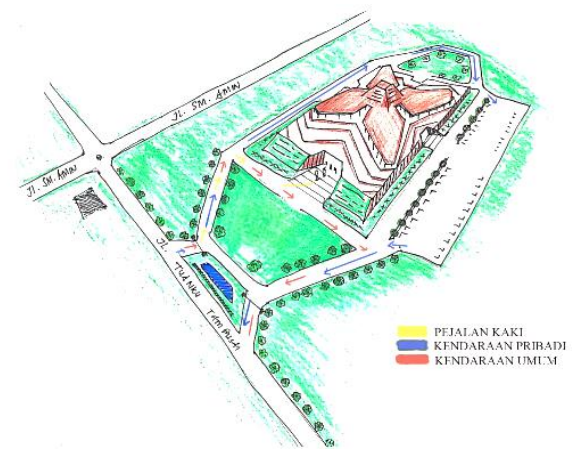

Gambar 9. Sirkulasi

(Sumber: Analisa Penulis, 2020)

Konsep Ruang Interior, ruang pertunjukkan mengekspos material seperti kayu dan menerapakan sistem pengaret seperti pada soko guru pada plafon langit-langit agar memberikan kesan Jawa yang natural. Desain dinding dengan bentuk seperti zigzag berguna untuk menghantarkan suara dari panggung sampai kebelakang bangunan agar penonoton dapat menikmati pertunjukkan walau jauh dari panggung.

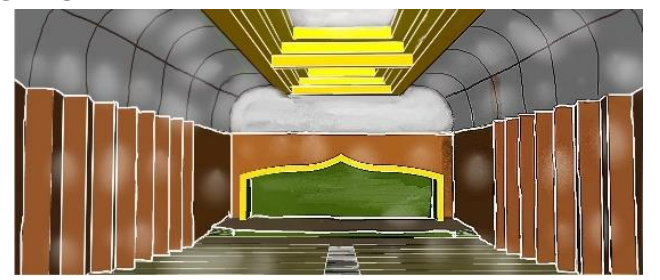

Gambar 10. Konsep Ruang Interior (Sumber: Analisa Penulis, 2020)

\section{KESIMPULAN DAN SARAN}

\section{Kesimpulan}

Hasil dari penulisan Laporan Seminar Arsitektur yang berjudul Pusat Pertunjukkan Kesenian Jawa di Pekanbaru dengan Pendekatan Arsitektur Jawa dapat disimpulkan sebagai berikut:

Pusat Perrtunjukkan Kesenian Jawa di Pekanbaru dengan Pendekatan Arsitektur Jawa dirancang untuk mewadahi aktivitas kesenian dengan memberikan fasilitas yang dibutuhkan baik dalam pelatihan hingga ke pertunjukkan kesenian Jawa. Pusat Pertnjukkan Kesenian Jawa di Pekanbaru dengan Pendekatan Arsitektur Jawa memberikan edukasi seni sekaligus menyambung regenarasi pelestari kesenian Jawa. Pusat Pertunjukkan Kesenian Jawa menerapkan cara pengambilan konsep dan Prinsip desain dari Arsitektur Jawa. Penerapannya menggunakan beberapa elemen yang terdapat pada bangunan berarsitektur Jawa. Hal ini dilakukan untuk memberi tahu bahwa arsitektur tradisional itu sifatnya dinamis dan arsitektur tadisional di Indonesia sangat banyak dan beragam.

\section{Saran}

Saran untuk perancangan Pusat Pertunjukkan Kesenian Jawa di Pekanbaru dengan Pendekatan Arsitektur Jawa harus memiliki sirkulasi yang baik, fasilitas yang mendukung aktivitas pertunjukkan kesenian Jawa agar segala aktivitas berjalan lancer. Pemahaman mengenai tema dan fungsi harus lebih di perhatikan dalam merancang agar segala kendala dapat teratasi untuk menuju ketahap perancangan berikutnya secara lebih maksimal.

\section{DAFTAR PUSTAKA}

Badan Pusat Statistik [BPS]. 2010. Kewarganegaraan, Suku Bangsa, Agama, dan Sehari-hari Penduduk 
Indonesia. 2010. Badan Pusat Statistik, JakartaIndonesia.

Damajanti, Irma. 2006. "psikologi seni" buku ajar. Bandung: PT. Kiblat Buku Utama.

Geertz, Clifford. 1993. "Art as Cultural System" dalam Local Knowledge Further Essays in

Interpretive Anthropology. New

York: Basic Book.

Pitana, T.S. 2001. The Javanese Cosmology and Its Influence on Javanese Arcitecture (Thesis). Australia: James Cook University.

Poerdarminto, Wjs. 2003. Kamus Besar Bahasa Indonesia. Jakarta: Balai Pustaka.

Soedarso, SP. 2006. Trilogi Seni- Penciptaan, Eksistensi, dan Kegunaan Seni. Yogyakarta: Badan Penerbit ISI Yogyakarta.

Sudarmaji. 1979. Dasar-dasar Kritik Seni Rupa. Jakarta: dinas museum dan sejarah, pemerintah DKI Jakarta.

Wardana, wisnoe, M.R. 1990. Pendidikan Seni Tari. Jakarta: PT. New Aqua Press.

Zein M, Wiryoprawiro. 1985. Arsitektur Jawa: Ayu, Ayom dan Ayem. Panunggalan, Surabaya: Bina Ilmu. 